\title{
FOREIGN LANGUAGE EDUCATION AT THE CURRENT STAGE OF DEVELOPMENT OF SOCIETY AND ITS PROSPECTS
}

\author{
Sarvara T. Akobirova \\ Associate Professor, Phd. Tashkent State Law University Tashkent, Uzbekistan \\ Sh.U.Khalilov
}

Student Tashkent State Law University Tashkent, Uzbekistan

\section{ABSTRACT}

This article discusses foreign language education at the current stage of development of society and its prospects. Today, the knowledge of a foreign language is very important, so reforming the system of foreign language teaching, the use of advanced interactive methods of teaching using modern pedagogical and information and communication technologies in the teaching process has become one of the most pressing issues in education. At the same time, the growing role of the independent Republic in the world community and the expansion of economic, political, social and cultural ties with foreign countries increase the need for our future generation to know a foreign language perfectly.

In this article, we tried to give some new opinions about changes which are happening in Uzbekistan.

KEYWORDS: - Foreign language, Uzbekistan, society, higher education system.

\section{INTRODUCTION}

Globalization and integration processes are taking place worldwide. This, in turn, will have a positive impact on all areas, allowing them to develop in all directions. The importance of foreign languages in this process is growing. They not only require language learners to know the language and communicate phonetically, lexically and grammatically correctly in the language they are learning, but also to teach them the customs, traditions, geography, foreign and domestic policy, and history of the people of the country where the language is studied. covers. One of the more important objects of education is the preparation for intercultural communication, taking into account the individual characteristics and life experiences of the communicator (speaker) with a foreign language medium.

\section{THE MAIN RESULTS AND FINDINGS}

Such an increasing importance of knowledge of a foreign language, the expansion of its functions are based on scientific and methodological factors, such as recently emerging theories, teachings, the results of research conducted around the world in the methodology of teaching 
CURRENT RESEARCH JOURNAL OF PEDAGOGICS 2(12): 124-129,

December 2021 DOI: https://doi.org/10.37547/pedagogics-crjp-02-12-25

ISSN 2767-3278

(C)2021 Master Journals

Crossref do: 81 Google

Accepted 19th December, 2021 \& Published 24 ${ }^{\text {th }}$ December, 2021

foreign languages. The growing importance of foreign languages in the processes of globalization and integration on a global scale, and the fact that they consider foreign languages as an important tool, requires a radical reconsideration and reform of linguodidactics and methods of teaching foreign languages.

Education is a process that requires constant renewal and reform. From the first days of our independence, our government, as in all areas, has paid special attention to the radical reform of education. Today, the content of education and teaching methods in higher education institutions have changed radically.

This, in turn, was one of the first steps taken to further improve the learning of foreign languages. In our country, serious attention is paid to the teaching and learning of foreign languages. In this regard, the decrees of the President of the Republic of Uzbekistan, the decisions of the Cabinet of Ministers and the Ministry of Higher and Secondary Special Education on further improving the teaching and learning of foreign languages are proof of our opinion.

Today, the knowledge of a foreign language is very important, so reforming the system of foreign language teaching, the use of advanced interactive methods of teaching using modern pedagogical and information and communication technologies in the teaching process has become one of the most pressing issues in education. At the same time, the growing role of the independent Republic in the world community and the expansion of economic, political, social and cultural ties with foreign countries increase the need for our future generation to know a foreign language perfectly.

On December 10, 2012, the First President of the Republic of Uzbekistan I.Karimov signed a decree "On measures to further improve the system of learning foreign languages" No. PP-1875,
Resolutions of the President of Uzbekistan Sh. Mirziyoyev dated April 20, 2017 No. PP-2909 "On measures for further development of the higher education system" and October 8, 2019 No. PF-5847 "On approval of the Concept of development of the higher education system of the Republic of Uzbekistan until 2030" development of foreign language education, It has a special significance as it focuses on such noble goals as training the younger generation as mature professionals in line with modern requirements.

An important aspect of these Resolutions is that they provide for the organization of continuous learning of foreign languages at all levels of the education system, as well as to improve the skills of teachers and further improve the provision of modern teaching and methodological resources, the introduction of advanced teaching methods using modern pedagogical and information and communication technologies, to further increase the interest of the younger generation in foreign languages and, in turn, to radically improve the system of training specialists who are fluent in foreign languages, as well as their achievements in world civilization and creation of conditions and opportunities for wide use of world information resources, development of international cooperation and dialogue.

These resolutions have entrusted the relevant government agencies, including all educational institutions and foreign language teachers, with the great task of educating the younger generation as high potential and knowledge that will further enhance the image of our independent state in the world community.

The legal framework for the radical reform of the training system in our country has been created, goals and objectives have been identified, The problems in this area, ways, stages of solving them and priorities for the implementation of reforms have been identified. These reforms are 
CURRENT RESEARCH JOURNAL OF PEDAGOGICS 2(12): 124-129,

December 2021 DOI: https://doi.org/10.37547/pedagogics-crjp-02-12-25

ISSN 2767-3278

(C)2021 Master Journals

Crossref do: 81 Google

Accepted 19th December, 2021 \& Published 24 ${ }^{\text {th }}$ December, 2021

aimed at improving the quality of training, including the use of new teaching technologies at all stages of the education system. The main task is to provide students with textbooks (textbooks, manuals and teaching aids) based on state educational standards.

As a logical continuation of the improvement of the regulatory framework, on May 19, 2021, the President of the Republic of Uzbekistan adopted Resolution No. PP-5117 "On measures to bring the teaching of foreign languages in the Republic of Uzbekistan to a qualitatively new level". The main purpose of this decision is to develop the teaching of foreign languages as a priority of education policy, to further improve the quality of education in this area, Attracting qualified personnel to educational institutions and, most importantly, developing the skills to independently create a sufficient database for young people to become aware of the latest achievements of science and become mature professionals in their field. One of the important changes in the resolution is that the Agency for the Promotion of Foreign Languages and its Republic of Karakalpakstan, The activities of regional representatives in the regions and the city of Tashkent are being established. We can see the importance of the changes that are expected to take place in the framework of the establishment of this structure, and we can take this as a prelude to efforts to develop the industry.

Schools, which are the threshold of knowledge, serve as the cornerstone of the sciences that a person acquires throughout his life. After all, "knowledge acquired in youth is like a pattern carved in stone". As a practical expression of this saying, we can see that in recent years a great deal of attention has been paid to the development of school education. In particular, the resolution stipulates that starting from the next academic year, schools specializing in foreign language teaching will be established in
207 districts (cities). Competitions will be organized among schools at the district (city), regional and national levels, and the winners will be awarded cash prizes of up to 100 million, 250 million and 500 million soums, respectively. A system of one-time subsidies of up to 50 million soums will be introduced for entrepreneurs who have established foreign language training centers in rural areas.

The demand for professional pedagogical staff, which is the creator of education, is growing from year to year. The effectiveness of the work carried out in this area depends in many respects directly on the teachers who are the owners of this honorable profession. Therefore, the resolution stipulates that from the 2021/2022 academic year, the practice of paying $50 \%$ more than the base rate will be introduced for foreign language teachers who have mastered a foreign language at $\mathrm{C} 1$ and above. This, of course, is recognized as a continuation of the ongoing reforms to attract leading professionals to the industry and to provide social support to existing ones.

Today, new textbooks, textbooks and teaching aids are being created. They are aimed at increasing students' literacy, developing speech, developing mental abilities, improving logical thinking, creative thinking and ensuring continuity between education systems. Effective use of modern pedagogical technologies in the process of teaching a foreign language will further increase the student's interest in the language and ensure that they have a high level of knowledge, skills and abilities acquired in the language.

The role of a foreign language in enhancing the professional competence of law students is enormous. Today, at the bachelor's and master's levels of Tashkent State University, practical training in foreign languages (English, German, French) is conducted on the basis of curricula 
CURRENT RESEARCH JOURNAL OF PEDAGOGICS 2(12): 124-129,

December 2021 DOI: https://doi.org/10.37547/pedagogics-crjp-02-12-25

ISSN 2767-3278

(C)2021 Master Journals

Crossref dof 81 Google

Accepted 19th December, 2021 \& Published 24 ${ }^{\text {th }}$ December, 2021

developed on the subject modules "Foreign language for lawyers" and "Language of foreign specialties".

Decree of the President of the Republic of Uzbekistan Sh.Mirziyoev dated April 29, 2020 No PD-5987 "On additional measures to radically improve legal education and science in the Republic of Uzbekistan" placed a high level of trust and responsibility on all professors, teachers and researchers in the field of legal education.

This decree outlines a number of tasks that we teachers have to deal with:

- training of highly qualified, creative, honest personnel in accordance with modern requirements and international needs;

- Improving the credit-module system of education, the widespread use of modern information and communication technologies in the educational process and the modernization of the educational base;

- intensification of cooperation with leading educational and scientific institutions of developed countries, joint legal research, exchange of professors and students;

- implementation of joint educational programs (double degree) on training of legal personnel together with foreign partners, active involvement of foreign scientists and specialists in the educational process;

- increase the competitiveness of national legal education at the international level;

- Establishment of comparative law training centers with Nagoya University of Japan, Regensburg University of the Federal Republic of Germany, higher education institutions of the United Kingdom and the People's Republic of China;

- Translation and publication of textbooks on legal sciences by foreign scholars in the state language in 2020-2025;

- creating new generation textbooks and textbooks with international partners.

10. Such as the organization of distance, parttime and evening forms of training.

The main task of our educators is to bring up and educate young people as perfect, perfect human beings. Therefore, at a time when the country's prestige in the world community is growing, the need for young professionals with all-round potential in the development of political, economic, cultural spheres and dialogue with foreign partners is growing.

Legal foreign language plays a key role in increasing the professional competence of law students. We list the following tasks of a foreign language in the systematic study of the judicial systems of developed countries, international organizations and the prospects of the legal profession:

1) facilitating the study of judicial and legislative systems of foreign countries (USA, UK, Germany, France);

2) access to world jurisprudence;

3) achieving a study of international law;

4) analysis of scientific research in the field of law studied abroad;

5) practical assistance to foreign joint ventures;

6) increase professional competence in the field of law;

7) reading and studying original legal literature in a foreign language;

8) facilitating participation in international conferences, meetings, seminars;

9) writing and defending the dissertations of law students (masters) in a foreign 
CURRENT RESEARCH JOURNAL OF PEDAGOGICS 2(12): 124-129,

December 2021 DOI: https://doi.org/10.37547/pedagogics-crjp-02-12-25

ISSN 2767-3278

(C)2021 Master Journals

Crossref do) 81 Google

Accepted 19th December, 2021 \& Published 24 ${ }^{\text {th }}$ December, 2021

language;

10) to study in foreign universities in order to develop the professional skills of lawyers.

Based on these tasks, foreign language education in law institutions has the following goals: practical, educational, pedagogical, developmental, professional.

Practical purpose - formation of oral and written legal speech in a foreign language.

Educational purpose - providing an opportunity to get acquainted with the culture of the countries where the language is studied, the formation of communicative, linguistic and sociolinguistic competence in students.

Developmental goal - language skills native language and culture of speech in a foreign language, general education skills aimed at developing a serious interest in learning a foreign language.

Professional purpose - it is aimed at in-depth study of legal terms in the formation of the professional competence of future lawyers and further improvement of students' speaking skills in a professionally oriented manner. In this regard, the professional-legal goal has a special place in foreign language education, as well as determines the content of other (primary) goals. Clearly, the first four goals are subject to the latter, i.e., the achievement of these goals will undoubtedly shape the professional speaking skills of law students.

It should be noted that a special (professional) approach is envisaged to further expand the content of the objectives of foreign language education in law institutions. In order to further develop foreign language education and improve the quality of education, the creation of textbooks, curricula, teaching aids is our main task as educators, and this will allow us to train high-level lawyers in the international arena.

\section{Conclusion}

In short, one of the tasks facing our youth, who are the main link in our society, is to bring our country to the ranks of the most advanced, developed countries in the world, as well as a thorough study of modern scientific and technological achievements, Thorough knowledge of foreign languages is important for them to become high-level international staff. Only then will a solid foundation be laid for Uzbekistan to take a worthy place among the world's leading countries and for our future to be great.

\section{REFERENCES}

1. Rubtsova, A. V., \& Almazova, N. I. (2019, February). Productive model of foreign languages learning: Realities and prospects. In International Conference Communicative Strategies of Information Society (CSIS 2018). Atlantis Press. https://doi. org/10.2991/csis-18.2019 (Vol. 65).

2. Tuevna, A. S. (2021). The Ways of Expressing Condolences Implicitly And Their Effect On Sociolinguistics. Turkish Journal of Computer and Mathematics Education (TURCOMAT), 12(4), 10991103.

3. Davis, J. N. (1997). Educational reform and the Babel (babble) of culture: Prospects for the standards for foreign language learning. The Modern Language Journal, 81(2), 151-163.

4. Akobirova, S. (2016). Features language interaction and the special status of English in globalization. SCIENTIFIC ENQUIRY IN THE CONTEMPORARY WORLD: THEORETICAL BASICS AND 
CURRENT RESEARCH JOURNAL OF PEDAGOGICS 2(12): 124-129,

December 2021 DOI: https://doi.org/10.37547/pedagogics-crjp-02-12-25

ISSN 2767-3278

(C)2021 Master Journals

Crossref do: 81 Google

Accepted 19 $9^{\text {th }}$ December, 2021 \& Published 24th December, 2021

INNOVATIVE APPROACH, 112.

5. Xiaojia, L. L. S. (2004). The GrammarTranslation Teaching Method: Retrospect, Current Status and Prospect [J]. Foreign Language Education, 1, 1-20.

6. Tuyevna, A. S., \& Turakulovich, N. R. (2019). Social Problems Reflected through Literature (On John Grisham's Creativity). International Journal of Progressive Sciences and Technologies, 18(1), 48-52.

7. Bakhriddinova, M., \& Mamadayupova, V. (2021). On The Process of Thematic Consolidation Of Legal Terms. Psychology and Education Journal, 58(1), 4942-4946.

8. BAKHRIDDINOVA, M. THE LINGUISTIC FEATURES OF DIALOGUE DISCOURSE REFERRING TO ITS BEING USED IN FOLKS.

9. Roby, W. B. (1992). Intercultural communication education and foreign language education: Shared precedents, procedures, and prospects. Intercultural Communication Studies, 2(1), 43-56.

10. Urinboevna, K. D., Gapporovna, S. M., Zagirovna, S. E., Kamalovna, N. U., \& Yulduz, K. (2019). Creation and use of teaching electronic multimedia books when teaching languages to learners and students in the republic of Uzbekistan. Journal of Advanced Research in Dynamical and Control Systems, 11(10 Special Issue), 1039-1045.

11. Ivlev, V. Y., Barkova, E. V., Ivleva, M. I., \& Buzskaya, O. M. (2016). Environmental Approach to the Study of the Modern Stage of Information Society Development: Research Prospects. International Journal of Environmental and Science Education, 11(16), 9113-9124.

12. Shamsitdinova, M. G. (2021). Methods of Teaching Listening Comprehension in ESP
Classes. Indiana Journal of Humanities and Social Sciences, 2(11), 1-8.

13. SAIDAZIMOVA, U. T. (2021). The issue of two women in the korean art world. Journal of Contemporary Issues in Business and Government, 27(3), 303-308.

14. Shamsitdinova, M. G. (2021). To the Review of Difficulties in Teaching Listening Comprehension to Law Students in English Classes. International Journal of Early Childhood Special Education, 13(1).

15. Hasanova, D. (2007). Teaching and learning English in Uzbekistan. English Today, 23(1), 3-9.

16. Raximovna, B. M., \& Farxodovna, K. D. (2020). VOCABULARY RETENTION IN COGNITIVE THEORY. Journal of Critical Reviews, 7(2), 402-404.

17. Bakhriddinova, M., \& Mamadayupova, V. (2021). On The Process of Thematic Consolidation Of Legal Terms. Psychology and Education Journal, 58(1), 4942-4946. 